\title{
A study of height, weight and body mass index in Nepalese
}

\author{
Prakash Baral $^{\star 1}$, Rami Shrestha1, Ratindra Nath Shrestha², Dinesh Banstola ${ }^{3}$, Rajesh Prajapati ${ }^{4}$ \\ Anatomy Department, Gandaki Medical College Teaching Hospital and Research Center, ${ }^{2}$ Anatomy Department, \\ Institute of Medicine, ${ }^{3}$ Physiology Department, Karnali Institute of Health Sciences, ${ }^{4}$ Physiology Department, \\ Gandaki Medical College Teaching Hospital and Research Center
}

\begin{abstract}
Introduction: The height measurement is an important anthropometric measurement which can be directly correlated with health status of an individual. Body weight of an individual refers to total body mass and is also important indicator of health status of people. Body mass index is a key index for relating weight to height. It is defined as the body mass divided by the square of the body height. The body mass index is an attempt to quantify the amount of body tissue mass in an individual, and then categorize that the person as underweight, normal weight, overweight or obese. The objective of our study was to find out the average height and weight, to calculate body mass index and find out its average value and to correlate height and weight in Nepalese population. Methods: A cross-sectional study was conducted in subjects from different parts of Nepal. Three hundred twenty one healthy subjects of 25 to 40 years of age group were studied. Height and weight of subjects were recorded and body mass index was calculated. Data were analyzed using Statistical Package for Social Sciences. Results: In overall Nepalese population, mean height was found to be $156.6 \pm 6.3 \mathrm{~cm}$; mean weight $56.6 \pm 11.4 \mathrm{~kg}$ and body mass index $20.9 \pm 1.8 \mathrm{~kg} / \mathrm{m}^{2}$. Pearson's correlation co-efficient for height and weight was 0.88. Conclusions: There was partial positive correlation between height and weight. There was statistically significant difference in height, weight and body mass index between Nepalese male and female $(p<0.05)$.
\end{abstract}

Key words: Body mass index, height, Nepalese, weight.

\section{*Correspondence:}

Dr. Prakash Baral

Professor, Anatomy Department,

Gandaki Medical College Teaching Hospital,

Pokhara, Nepal

Email: prakashbaral2002@gmail.com

Submitted: September 28, 2021

Accepted: November 24, 2021

To cite: Baral P, Shrestha R, Shrestha RN, Banstola D, Prajapati R. A study of height, weight and body mass index in Nepalese. JGMC Nepal. 2021;14(2):88-92.

DOI: $10.3126 /$ jgmcn.v14i2.40021

\section{INTRODUCTION}

Anatomic height of human body refers to a measurement from cranial vertex to lower border of foot when a person without shoes stand with their back to the wall in such a way that the back of feet, calves, upper back and the back of their head should be in contact with the wall and look directly forward. The height of a person signifies the health status of an individual such as person with low height may suffer from genetic disorder, endocrine disorder, nutrition deficiency, metabolic disorder, blood diseases, cardiac diseases, pulmonary diseases etc. Person with higher height may suffer from endocrine disorder, genetic diseases, pituitary adenoma etc. Thus, height measurement is an important anthropometric measurement which can be directly correlated with health status of an individual. The average height of population of a country can indicate the health state of that country. For example, average height of population of developed country is higher than that of underdeveloped country because people of developed country are well nourished as compared to that of underdeveloped countries.

Body weight of an individual refers to total body mass. Thus, body 
mass should be weighed on weighing machine by taking out all heavy items like shoes, keys, wallet, jacket, woolen garments etc. Body weight is also important indicator of health status of people. Low body weight of an individual may indicate that person suffers from endocrine disorder (like diabetes mellitus), nutrition deficiency, metabolic disorder, blood diseases, cardiac diseases, pulmonary diseases etc. Person with higher/overweight may indicate over nutrition, endocrine disorder (like hypothyroidism) or hypothalamic diseases like suppression of satiety center etc. The average weight of population of a country can indicate the health state of that country. For example, average weight of population of developed country is optimally higher than that of underdeveloped country because people of developed country are well nourished as compared to that of underdeveloped countries.

The height and weight are depending variables. As the height increases the weight increases and vice-versa. Thus, there is positive correlation between height and weight.

Body mass index (BMI) is a key index for relating weight to height. It is defined as the body mass divided by the square of the body height, and is universally expressed in units of $\mathrm{kg} / \mathrm{m}^{2}$. The BMI is an attempt to quantify the amount of body tissue mass in an individual, and then categorize that the person as underweight, normal weight, overweight or obese.

WHO has classified bodyweight that include degrees of underweight and grades of overweight. These classifications are based on BMI, which is calculated as weight in kilograms divided by height in metre squared $\left(\mathrm{kg} / \mathrm{m}^{2}\right)$. BMI is easy to obtain as a measure of relative weight and is an acceptable proxy for thinness and fatness. ${ }^{1}$ BMI between 18.5 to $24.99 \mathrm{~kg} / \mathrm{m}^{2}$ is considered as ideal body weight, BMI between 25 to $30 \mathrm{~kg} / \mathrm{m}^{2}$ as overweight and BMI $>30 \mathrm{~kg} / \mathrm{m}^{2}$ as obese. ${ }^{2}$ With the mordernization, sedentary lifestyle and unhealthy eating habits, the prevalence of inactivity has increased among all age groups and is thought to be a major contributor to obesity. ${ }^{3}$ With this, the susceptibility to accumulate unhealthy amount of adipose tissues without significant weight change has been potentially increased. ${ }^{4}$ In recent years, obesity that reflects excessive amount of body fat has become a global health problem. It is associated with increased incidence of cardiovascular disease, diabetes, sleep apnea, degenerative joint disease and cancers.
Moreover, high obesity prevalence could potentially result in short life expectancy and affect in national productivity in long run..$^{4-7}$ Obesity is a burning issue in public health because of its increasing trend not only in developed countries but also in developing countries like Nepal. ${ }^{6,8}$ Not only this, underweight or low BMI is also a serious problem since it suggests low nutritional status of individual. BMI has been found to be different in different cultural groups and ethnicity in studies in other countries. Since the study of BMI documents the anthropometric record and help to access the nutritional status of that country, this type of study will help government for national planning.

As there was a need to measure the height, weight and calculate BMI of the subjects from different parts of Nepal i.e. mountain, hilly and plain districts of Eastern, Middle and Western parts for the representative data, this study was undertaken. The objective of this study was to find out the average height and weight of Nepalese population, to correlate the height and weight and to calculate BMI and find out average BMI value of Nepalese population.

\section{METHODS}

A cross- sectional study was conducted in communities in Pokhara metropolitan city i.e.ward no.5, 6, 7and 8 (Malepatan, Baidam, Masbar and Simalchaur area) where the subjects were coming for work/job from different parts of Nepal i.e. mountain, hilly and plain districts of Eastern, Middle and Western parts. The study was conducted from Magh 2070 to Falgun 2074 BS. Simple random sampling method was adopted for the study. The sample size was calculated by using formula, $n=\mathrm{s}^{2} / \mathrm{e}^{2}$ where $\mathrm{s}$ is standard deviation and $\mathrm{e}$ is standard error. From the previous pilot study, the standard deviation was calculated as 6.3 and standard error as 0.36 . Thus, number of study subjects were 306 . Total 321 healthy subjects of 25 to 40 years of age group without any endocrine, metabolic and genetic disorders were included for the study. Out of 321 subjects from diverse communities, 161 were male and 160 were female. Subjects with limb and spinal injuries, childhood chronic illness like anemia and asthma which could affect their height and body weight were excluded. Ethical clearance was obtained from institutional ethical committee of Gandaki Medical College prior to conducting the research (Ref. No.: 21-08-070). Verbal consent was taken for measurement of height and weight as these were very simple measurements. Subjects gave consent readily and 
happily as they could check their body weight and height free of cost and become aware of their status of obesity with their calculated BMI score. For the measurement of height, subjects were asked to stand in anatomical position and subject's head positioned in Frankfurt horizontal plane. They were asked to take off their shoes and stand with their back to the wall in such a way that the back of feet, calves, upper back and the back of their head should be in contact with the wall and look directly forward. Then height of subjects was measured on bare feet from lower border of sole to vertex of skull with Stadiometer. Weight of subjects was recorded with weighing machine in kilograms (Kg). Subjects were asked to take out heavy clothes like sweater, jackets, wallets and shoes for this purpose. The weighing machine was set to zero first then subject was asked to step up over it and reading was taken after the needle of the machine got settled. Then BMI was calculated using the formula i.e. BMI=weight in $\mathrm{kg} /$ height in meter. $^{2}$ To ensure good reliability and validity of research interobserver bias was eliminated and instruments measuring height (stadiometer) and weigh machine were calibrated with standard scale and rechecking of readings were done.

Data were entered in excel sheet and analysis were performed using Statistical Package for Social Sciences version 16.0. Mean and standard deviation were calculated. The ' $\mathrm{Z}$ 'test was applied to test the significant difference between male and female variables. A 95\% confidence interval was set to observe the difference ( $P$ value). The Pearson's correlation was used to correlate between height and weight.

\section{RESULTS}

Three hundred and twenty one subjects participated in our study out of which 161 were males and 160 were females.

Table 1: Distribution of research subjects region wise in Nepal

\begin{tabular}{|c|c|c|c|c|c|c|c|c|c|c|c|}
\hline \multirow[t]{2}{*}{ S.N. } & \multirow[t]{2}{*}{ Sex } & \multicolumn{3}{|c|}{ Mountain region } & \multicolumn{3}{|c|}{ Hilly region } & \multicolumn{3}{|c|}{ Plain region } & \multirow[t]{2}{*}{$\begin{array}{l}\text { Grand } \\
\text { total }\end{array}$} \\
\hline & & Eastern & Middle & Western & Eastern & Middle & Western & Eastern & Middle & Western & \\
\hline 1 & Male & 17 & 18 & 17 & 20 & 18 & 17 & 18 & 19 & 17 & 161 \\
\hline 2 & Female & 15 & 19 & 17 & 17 & 20 & 18 & 17 & 19 & 18 & 160 \\
\hline \multicolumn{11}{|c|}{ Grand total } & 321 \\
\hline
\end{tabular}

Mean height, weight and BMI of Nepalese population were calculated and presented in table 2 .
Table 2: Mean height, weight and BMI in Nepalese (N=321)

\begin{tabular}{ccc}
\hline S.No. & Variable & Mean \pm SD \\
1. & Height in $\mathrm{cm}$ & $156.6 \pm 6.3$ \\
2. & Weight in Kg & $56.6 \pm 11.4$ \\
3. & BMI & $20.9 \pm 1.8$ \\
\hline
\end{tabular}

Mean height of Nepalese was found to be $156.6 \pm 6.3$ $\mathrm{cm}$; mean weight $56.6 \pm 11.4 \mathrm{~kg}$ and BMI $20.9 \pm 1.8 \mathrm{~kg} /$ $\mathrm{m}^{2}$. Height and weight correlation was done. There was partial positive correlation between height and weight i.e. correlation co-efficient $r=0.88$. It is plotted in the graph as presented in figure 1.

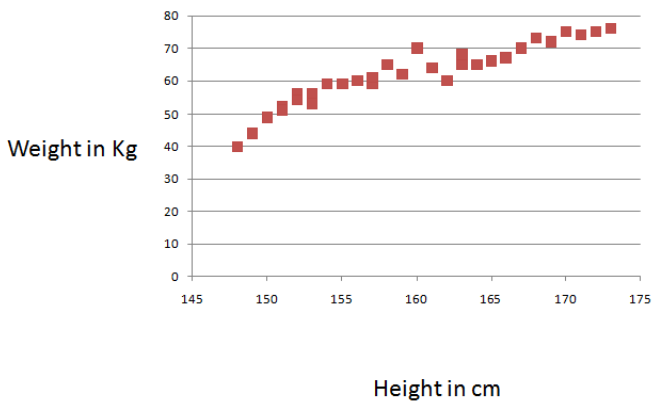

Figure 1: Correlation between height and weight

Variations in mean height, weight and BMI between males and females was studied and presented in table 3.

Table 3: Mean height, weight and BMI in Nepali population sex wise

\begin{tabular}{cccc}
\hline & Male & Female & P value \\
$\begin{array}{c}\text { Mean height } \pm \text { S.D } \\
\text { (cm) }\end{array}$ & $163.1 \pm 6.4$ & $151.5 \pm 6.2$ & $0.00001^{*}$ \\
$\begin{array}{c}\text { Mean weight } \pm \\
\text { S.D kg }\end{array}$ & $61.7 \pm 13.2$ & $50.5 \pm 9.3$ & $0.00001^{*}$ \\
Mean BMI \pm S.D. & $21.8 \pm 4.7$ & $19.6 \pm 4.1$ & $0.00001^{*}$ \\
\hline
\end{tabular}

*statistically significant

In the present study, it was found that height, weight and BMI of Nepalese male was $163.1 \pm 6.4 \mathrm{~cm}, 61.7 \pm$ $13.2 \mathrm{~kg}$ and $21.8 \pm 4.7 \mathrm{~kg} / \mathrm{m}^{2}$ and that of female is 151.5 $\pm 6.2 \mathrm{~cm}, 50.5 \pm 9.3 \mathrm{~kg}$ and $19.6 \pm 4.1$ and the difference was statistically significant $(\mathrm{p}<0.001)$. There was a partial positive correlation between weight and height in both male and female i.e. correlation coefficient $(r)=0.91$ for males, 0.84 for females.

\section{DISCUSSION}

The height, weight and BMI depends on genetic, nutrition and state of endocrine gland. As seen in Gurkha-British record, the average height of Nepalese during second 
world war was 5 feet 2 inch but now it was 5 feet 4 inch. It may be due to improvement in socioeconomic status/ living conditions of Nepalese. Nepalese are well nourished now-a-days as compared to $2^{\text {nd }}$ world era. The genetic role in determination of the height of an individual can be proven by an observation that Japanese people are shorter in height though they are well nourished.

The association between body weight and height has been examined in several prospective studies. In the present study, BMI of average Nepalese population was found to be around $21 \mathrm{~kg} / \mathrm{m}^{2}$ which is within normal range as per WHO recommendation. Similarly, BMI of male population is around $22 \mathrm{~kg} / \mathrm{m}^{2}$ and female is around $20 \mathrm{~kg} / \mathrm{m}^{2}$ which lie in normal range as well. This value is comparable to the reports in Nepalese medical students in which most students were found to be within ideal BMI category. ${ }^{6}$ Similarly, in other study performed in Nepalese population by Shah et al. non-diabetic subjects were found to have BMI within normal range which is in consistency to our study. ${ }^{9}$

The finding of our study also coincides with the study in Asians, Caucasians, Hispanics and others in which AsianAmericans had the lowest BMI as compared to other groups. ${ }^{4}$ In another study by Vyas et al. BMI of both city and rural boys were less than $18 \mathrm{~kg} / \mathrm{m}^{2}$. However, city boys were found to be heavier than rural boys but there was no significant difference statistically. This result is in contrast to our study in which average Nepalese population had BMI within normal range. ${ }^{10}$

The study in Maltese children revealed that over a quarter of those children were either overweight or obese and the proportion rose to $40 \%$ in next study performed two years later. This result is also in contrast to our present study. ${ }^{5}$

\section{CONCLUSIONS}

In respect to the observation of present study, the mean height of average Nepalese population was found to be $156.6 \pm 6.3 \mathrm{~cm}$, mean height of male was $163.1 \pm 6.4 \mathrm{~cm}$ and that of female was $151.5 \pm 6.2 \mathrm{~cm}$. Similarly, mean weight of average Nepalese was $56.6 \pm 11.4 \mathrm{~kg}$, mean weight of male was $61.71 \pm 13.2 \mathrm{~kg}$ and of female $50.5 \pm 9.3 \mathrm{~kg}$. Likewise, our study also revealed that mean BMI of average Nepalese in overall population to be $20.9 \pm 1.8 \mathrm{~kg} / \mathrm{m}^{2}$, mean BMI of average male was $21.8 \pm 4.7 \mathrm{~kg} / \mathrm{m}^{2}$ and that of female was $19.6 \pm 4.1 \mathrm{~kg} / \mathrm{m}^{2}$. There was partial positive correlation between height and weight where the co-efficient of correlation (r) was 0.88 for overall population, 0.91 for male and 0.84 for female.

\section{LIMITATIONS}

In this study, data was collected from diverse geographical region of Nepal, however the number of subjects were less in each region. So, further extensive studies are required so that meta-analysis can be done to make a final conclusion.

\section{CONFLICT OF INTEREST: None}

\section{SOURCE OF FUNDING: None}

\section{REFERENCES}

1. WHO Expert Consultation. Appropriate Body mass index for Asian populations and its implications for policy and intervention strategies. Lancet. 2004;363:157-63. DOI:10.1016/s01406736(03)15268-3

2. World Health Organization. Obesity: Preventing and managing the global epidemic. Report on a WHO consultation. Technical Report Series No 894; World Health Organization: Geneva, Switzerland. 2000. Available at https://apps.who.int/iris/ handle/10665/42330

3. Barnes P. Physical Activity among Adults: United States, 2000 and 2005, National Center for Health Statistics, Hyattsville, Md, USA; CDC, Atlanta, USA, 2007. Available at http://www.cdc.gov/nchs/ products/pubs/pubd/hestats/physicalactivity/ physicalactivity.htm

4. Carpenter CL, Yan E, Chen S, Hong K, Arechiga A, Kim WS, et al. Body fat and body-mass index among a multiethnic sample of college-age men and women. J Obes. 2013;2013:790654. DOI: 10.1155/2013/790654 PMID: 23691288.

5. Farrugia Sant'Angelo V, Grech V. Comparison of body mass index of a national cohort of Maltese chidren over a 3-year interval. Malta Med Journal. 2011;23(1): 34-9.

6. Amatya M, Khanal B, Yadav SR. Body mass index of Nepalese medical students: A cross sectional study. Int J Dev Res. 2014;4(3):746-8. DOI: 10.18203/23946040.ijcmph20181692

7. Calle EE, Rodriguez C, Walker-Thurmond K, Thun 
MJ. Overweight, obesity, and mortality from cancer in a prospectively studied cohort of U.S. adults. NEJM. 2003;348(17):1625-38. DOI: 10.1056/ NEJMoa021423 PMID: 12711737.

8. Vaidya A, Shakya S, Krettek A. Obesity prevalence in Nepal: public health challenges in a low-income nation during an alarming worldwide trend. Int J Environ Res Public Health. 2010;7:2726-44. DOI:10.3390/ ijerph7062726 PMID: 20644698.
9. Shah A, Parthasarathi D, Sarkar D, Saha CG. A comparative study of body mass index (BMI) in diabetic and non-diabetic individuals in Nepalese population. Kathmandu Univ Med J. 2006;4(13):4-10.

10. Vyas MR, Thakur SJ, Parmar PP. Comparative Study of Body Composition between City and Rural Area Boys in Gandhinagar. Journal of Exercise Science and Physiotherapy, 2012; 8(1): 48-50. DOI: 10.18376//2012/v8i1/67606 